\title{
Long Term Trial of Two Dental Resins Used in the Manufacture of the Aesthetic Component of Fixed Restorations
}

\author{
GABRIELA CIAVOI ${ }^{1}$, ANAMARIA BECHIR ${ }^{2}$, EDWIN SEVER BECHIR ${ }^{3}$, FARAH CURT MOLA ${ }^{3}$, VALENTIN PRIBAC ${ }^{3}$, \\ ELENA SAPTE ${ }^{4 *}$, IONELA TEODORA DASCALU ${ }^{5}$ \\ ${ }^{1}$ University of Oradea, Faculty of Medicine and Pharmacy, 1 Decembrie Sq, 3700, Oradea, Romania \\ ${ }^{2}$ Titu Maiorescu University of Bucharest, Faculty of Dental Medicine, 67A Gh. Petrascu Str., 031593, Bucharest, Romania \\ ${ }^{3}$ University of Medicine and Pharmacy Tirgu Mures, Faculty of Dental Medicine, 38 Gheorghe Marinescu Str., 540139, Tirgu \\ Mures, Romania \\ ${ }^{4}$ Ovidius University of Constanta, Faculty of Dental Medicine, 7 Ilarie Voronca Str., 900684, Constana, Romania \\ ${ }^{5}$ University of Medicine and Pharmacy Craiova, Faculty of Dental Medicine, 2 Petru Rares Str., 200349, Craiova, Romania
}

\begin{abstract}
The fixed mixed prosthetic restorations (FMPRs) are often manufactured in dentistry. Fixed prosthetic restorations mixed (RPFM) are often used in dentistry. The aim of the study was the presentation of the deficiency and the differences arising between FMPRs with metallic framework plated with two types of dental resins, currently used frequently in Romania, Superpont $C+B$ (Spofadental, Czech Republic) and Royaldent (Palatine Foggyart, Hungary). We have achieved at 102 patients, 132 FMPRs coated with Superpont $C+B$ and Royaldent resins. Patients were divided into two equal groups according to dental polymer used for coating. Long-term study was conducted by biannual monitoring, over three years. The results of the study showed that both resins degrades over time, from the point of view of their physical appearance and their aesthetics, and induced the apparition of gingival inflammation, but restorations coated with Royaldent resin showed less irritation of the gingival tissues.
\end{abstract}

Keywords: Superpont $C+B$ and Royaldent dental resins, long term trial

Aesthetic considerations of recent decades represent some of the most important requirements in achieving the prosthetic treatments, and the longevity of dental restorations constitutes an important part of dental health. One of the aesthetic problems which can appear in the fixed mixed prosthetic restorations (FMPRs) is represented by the microleakage localised at the interface between the cast metallic framework and the resin layer [1]. The evolution of these microspaces can determine the coloration of the resins and can allow the accumulation of microorganisms in these regions, which can induce the apparition of gingival irritation [2]. The development of different types of heat curing methyl-polymethacrylate resins with application in dentistry beginning 1937 was considered a revolution in aesthetic component part of prosthetic restorations. Actually dental resins present acceptable properties, simple technology, but also disadvantages- such as dimension changes during elaboration, porosities, poor mechanical resistance [3]. Polymethyl methacrylate (PMMA) has been the most popular material used on artificial teeth fabrication since its introduction in 1937 [4]. Compared with the hard dental tissues PMMA shows different values in properties as toughness, compression resistance, thermal expansion, polymerization shrinkage and water absorption[5]. PMMA, an ester of methacrylic acid $\left(\mathrm{CH}_{2}=\mathrm{C}\left[\mathrm{CH}_{3}\right] \mathrm{CO}_{2} \mathrm{H}\right)$, belongs to the important acrylic family of resins. In modern production it is obtained principally from propylene, a compound refined from the lighter fractions of crude oil. Propylene and benzene are reacted together to form cumene, or isopropylbenzene; the cumene is oxidized to cumene hydroperoxide, which is treated with acid to form acetone; the acetone is in turn converted in a three-step process to methyl methacrylate $\left(\mathrm{CH}_{2}=\mathrm{C}\left[\mathrm{CH}_{3}\right] \mathrm{CO}_{2} \mathrm{CH}_{3}\right)$, a flammable liquid. Methyl methacrylate, in bulk liquid form or suspended as fine droplets in water, is polymerized (its molecules linked together in large numbers) under the influence of free-radical initiators to form solid PMMA [6]. The structure of the polymer repeating unit is presented in figure 1.

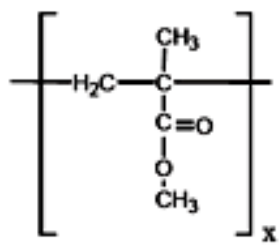

Fig. 1. The chemical structure of PMMA

Mechanical properties of PMMA are satisfactory, except the abrasion resistance, which is reduced. Optical properties are outstanding: the refractive index is close to that of dentin and enamel and transparency is excellent. Colouring possibilities are virtually limitless. Unfortunately these advantages are overshadowed by the PMMA yellowing over time Acrylate powder contains mainly polymer, pigments, plasticizers, initiator, and the liquid contains mostly-liquid monomer and a polymerization inhibitor [4].

Superpont $C+B$ is a crown and bridge acrylic resin for heat and pressure polymerization. The powder contain poly(methyl methacrylate), poly(methacrylate-co-butyl acrylate), pigments, and the liquid, methyl methacrylate, triethylene glycol dimethacrylate, and stabilizers. The powder is added to the liquid and mixed at the ratio mentioned above until a fine mixture is achieved. After several minutes, a plastic non-drying dough is formed which maintains its workability for at least $30 \mathrm{~min}$. It is applied directly to a gypsum model of the prepared teeth or the metallic denture. The prepared tooth model together with a resin layer is fastened to the special stand and placed into the pressure unit. The curing is carried out in glycerol, steam or water under conditions set by the manufacturer 
of the pressure curing unit. We recommend a minimum temperature of $93^{\circ} \mathrm{C}, 0.6 \mathrm{MPa}$ of pressure and $15-25 \mathrm{~min}$ [7]. When the curing is finished the product is left to cool, removed from the pressure unit, processed and polished in the usual manner [8-11].

Royaldent is also an crown and bridge acrylic resin for heat and pressure polymerization. The powder contain acrylic polymer based on methyl methacrylate, dibenzoyl, pigments, and the liquid, methyl methacrylate, ethylene glycol dimethacrylate, and an activating agent $\mathrm{N}$-dimethylp-toluidine N [12]. 2 parts powder is mixed with 1 part liquid and after some minutes the plastic, not-drying, pastalike material, can be puted directly onto the gypsum-model of the isolated tooth or on to the metal framew ork that will be covered correctly with the opaker. The dentin material should be put onto the whole surface of the opaker, the edge material should be put onto the edge third of the dentin, in the correct thickness, to reach the exact colour shade. The polymerization is either in glycerine or in water, in the polymerization machine, at the temperature of minim 93 Celsius degree, at the pressure of 6 atmosphere, for minimum 15 min $[13,14]$.

Figure 2 shows the manner of presenting of Superpont $C+B$ and Royaldent polymers, used in this research.
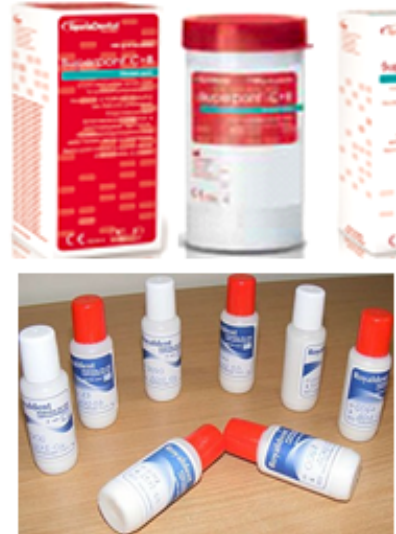

Fig. 2 Manner of presenting of the used dental polymers in research:

Superpont $C+B$ (top) and Royaldent (bottom)

FDI World Dental Federation approved in 2007 the new clinical criteria for the evaluation of direct and indirect restorations-update and clinical examples [15]. The new clinical criteria were categorized into three groups: esthetic parameters (four criteria), functional parameters (six criteria) and biological parameters (six criteria). Each criterion can be expressed with five scores, three for acceptable and two for non-acceptable (one for reparable and one for replacement). The criteria have been used in several clinical studies since their apparition, but the experience obtained in their application determined to a requirement to amending some of the originally criterion and scores [16]. Researchers often adapt the criteria in an effort to make them more discriminating for modern restorative materials, with the consequence that there are many so called modified Ryge criteria in use [17].

The aim of the study was the presentation of the deficiency and the differences arising between FMPRs with metallic framew ork plated with two types of dental resins, frequently used in Romania, Superpont C + B (Spofadental, Czech Republic) and Royaldent (Palatine Foggyart, Hungary).

\section{Experimental part}

Materials and methods

The researches were conducted in five Romanian Faculties of Dental Medicine. The clinical procedure for achievementFMPRs were standardized before the start of the investigation after a written detailed protocol. The clinical and technical phases for achievement FMPRs includes the examination and the patient history, tooth preparation, impression of prosthetic field, provisional protection, manufacturing the model, achieving the metallic framework, packing and getting the mold, melting and casting of metallic framework, unpacking, processing and finishing of metallic framework, conditioning and plating with the polymeric component of metallic framework, processing, finishing and polishing of FMPRs, checking and fixing of FMPRs to the provisional/final stage.

To 102 healthy patients we manufactured 132 FMPRs on 303 vital abutments and 17 devital abutments. Patients were divided into two equal groups according to dental polymer used for coating. 71 FMPRs of 51 patients (29 females and 22 males) were coated with Superpont $C+B$ (Spofadental, Czech Republic) and 61 FMPRs of 51 patients ( 28 females and 23 males) were coated were coated with Royaldent (Palatine company Foggyart Hungary) resins. Majority of the patients were female $(55.88 \%)$.

Patients were ranged from 38 to 53 years of age (mean age $45.5, \pm 7.5$ years).

In figure 3 is presented the distribution of patients and of FMPRs into the two groups.
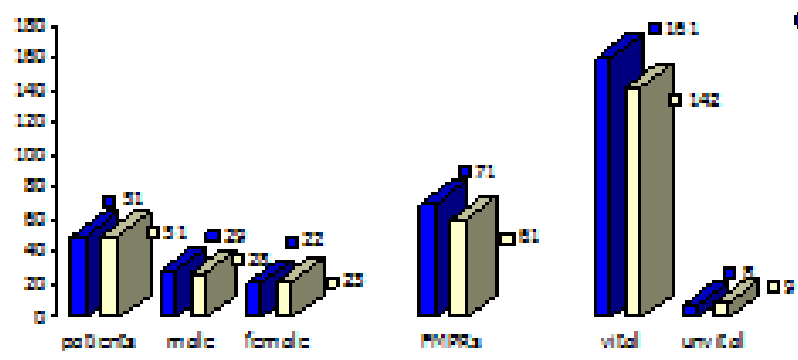

Superpont C+B

$\square$ Rovaldent

a

Fig. 3. Distribution of patients and FMPRs in groups

Selection criteria of patients consisted of patients free of any major disease processes, and all intraoral and extraoral conditions within normal limits, periodontally sound, and with normal occlusion. The study was explained to each patient recruited, to include the need of recalls at baseline and yearly, during of three years. Participation was voluntary for those selected and an informed consent form was signed by all volunteers at the start of the study. Each patient needs at least one anterior or posterior prosthetic restoration.

Long-term study was conducted by biannual monitoring, over three years. Dental practitioners completed the questionnaire with the modified Ryge criteria used in this study, at baseline (represented by the insertion of restoration in oral cavity) and during every recall.

The modified Ryge criteria used in this study were the followings:

-Criterion 1: Discolorations in FMPRs: were screened using Vita key, the colour were mentioned during every recall;

-Criterion 2: Surface texture: carried out with the light switched off and the at a distance of 60-100 cm;

-Criterion 3: Marginal integrity: realized by controlling directly in the mouth the cervical edge of the restorations, with explorers no. 17;

-Criterion 4: Gum problems: recorded in conformity with Loe \& Silness Gingival Index (GI);

-Criterion 5: Cervical caries: determined with explorers no. 17;

-Criterion 6: Pulp sensitivity: the presence of sensitivity to modifications of temperature and pressure (by using 


\begin{tabular}{|c|c|c|c|}
\hline & Criteria & Score & Characteristics \\
\hline \multirow[t]{4}{*}{1.} & \multirow{4}{*}{$\begin{array}{l}\text { Discolorations in } \\
\text { FMPRs }\end{array}$} & A & No evident discoloration \\
\hline & & $\mathrm{B}$ & Slight discoloration \\
\hline & & $\mathrm{C}$ & Evident discoloration \\
\hline & & $\mathrm{D}$ & Gross staining \\
\hline \multirow[t]{4}{*}{2.} & \multirow{4}{*}{ Surface texture } & $\overline{\mathrm{A} A}$ & Smooth surface \\
\hline & & $\mathrm{B}$ & Slightly rough \\
\hline & & $\mathrm{C}$ & Rough, cannot be refinished \\
\hline & & $\mathrm{D}$ & Deeply pitted surface \\
\hline \multirow[t]{4}{*}{3.} & \multirow{4}{*}{ Marginal integrity } & $\overline{\mathrm{A}}$ & Excellent, explorer does not catch or penetrate \\
\hline & & $\mathrm{B}$ & Explorer catches, slight cervice margin \\
\hline & & $\mathrm{C}$ & Evident crevice at margin \\
\hline & & $\mathrm{D}$ & Mobile, fractured or missed restoration \\
\hline \multirow[t]{4}{*}{4.} & \multirow{4}{*}{$\begin{array}{l}\text { Gum problems in } \\
\text { conformity with } \\
\text { Loe \& Silness } \\
\text { Gingival Index } \\
\text { (GI) }\end{array}$} & $0=\mathrm{A}$ & Normal gingiva \\
\hline & & $\mathrm{l}=\mathrm{B}$ & $\begin{array}{l}\text { Mild inflammation: Slight change in color, slight edema; } \\
\text { No bleeding on probing }\end{array}$ \\
\hline & & $2=\mathrm{C}$ & Moderate inflammation: Redness, edema, glazing, bleeding on probing \\
\hline & & $3=\mathrm{D}$ & $\begin{array}{l}\text { Severe inflammation: Marked rednes5, edema, ulceration; } \\
\text { Tendency to spontaneous bleeding }\end{array}$ \\
\hline \multirow[t]{2}{*}{ (5. } & \multirow{2}{*}{ Cervical caries } & $\overline{\mathrm{A}}$ & No caries \\
\hline & & $\mathrm{B}$ & Present caries \\
\hline \multirow[t]{3}{*}{6.} & \multirow{3}{*}{ Pulp sensitivity } & $\bar{A}$ & No sensitivity \\
\hline & & $\mathrm{B}$ & Occasionally sensitive \\
\hline & & $\mathrm{C}$ & Constantly sensitive \\
\hline
\end{tabular}

Table 1

MODIFIED RYGE CRITERIA USED IN THISSTUDY the tlow of air trom the dental unit), and by comparison with a healthy tooth, selected in the opposite quadrant.

Modified Ryge criteria used in this study is presented table 1. The Alfa $(A)$ value indicated that conditions were clinically ideal; Bravo (B) ratings indicated clinical acceptability; Charlie (C) and Delta (D) ratings were not noted at baseline/insertion of FMPRs in oral cavity, at six months and at one year.

\section{Results and discussions}

In 3 years we realised 7 records of data (initial determination at insertion of FMPRs and 6 recalls). Data were analyzed both in terms of numbers and statistics.

Table 2 summarizes the recorded results of the prosthetic restorations in percentages, after processing of data, in reference to the criteria set, after the evaluation period of three years.

Criterion 1: The colour changes occurred faster (at 12 months) in FMPRs covered with Superpont C+B than in FMPRs covered with Royaldent polymer (at 18 months). Also, the Superpont C+B polymer presented a greater discoloration rate than the Royaldent polymer.
Criterion 2: The modifications of surface texture in FMPRs covered with Superpont $C+B$ were observed beginning with the second recall (at 12 months) in contrast to that covered with Royaldent (18 months). Also, the percentage of modifications in surface texture in FMPRs covered with Superpont $C+B$ polymer was greater than in that of the Royaldent polymer.

Criterion 3: Marginal integrity: Plaque accumulation is more common in acrylic works due to the porous structure of the material they are made of. From analyzing past results in table we observed that in Superpont $C+B$, the accumulation of plaque is much faster and more patients, while at Royaldent, even at the last meeting number is of that previous group 8-15 (32\%-60\%).

Criterion 4: Gum problems in conformity with Loe $\&$ Silness gingival index (GI): We emphasis that FMPRs coated with Royaldent resin showed less irritation of the gingival tissues. Both dental resins affected the health status of surrounding soft tissues of cervical area of abutments, and at the end of the 3rd year of study were recorded high percentages of marginal periodontal problems.

Table 2

RECORDED RESULTS OF FMPRS AFTER PROCESSING OF DATA, IN REFERENCE TO THE CRITERIA SET

\begin{tabular}{|c|c|c|c|c|c|c|c|c|c|c|c|c|c|c|c|}
\hline & & \multicolumn{7}{|c|}{ Superpont C+B } & \multicolumn{7}{|c|}{ Royaldent } \\
\hline & & $\begin{array}{l}\text { Inser- } \\
\text { tion }\end{array}$ & $\begin{array}{c}6 \\
\text { month }\end{array}$ & $\begin{array}{c}12 \\
\text { month }\end{array}$ & $\begin{array}{c}18 \\
\text { month }\end{array}$ & $\begin{array}{c}24 \\
\text { month }\end{array}$ & $\begin{array}{c}30 \\
\text { month }\end{array}$ & $\begin{array}{c}36 \\
\text { month }\end{array}$ & $\begin{array}{l}\text { Inser } \\
\text { tion }\end{array}$ & $\begin{array}{c}6 \\
\text { month }\end{array}$ & $\begin{array}{c}12 \\
\text { month }\end{array}$ & $\begin{array}{c}18 \\
\text { month }\end{array}$ & $\begin{array}{c}24 \\
\text { month }\end{array}$ & $\begin{array}{c}30 \\
\text { month }\end{array}$ & $\begin{array}{c}6 \\
\text { month }\end{array}$ \\
\hline \multirow{4}{*}{$\begin{array}{l}\text { Discolorations } \\
\text { in FMPRs }\end{array}$} & $\bar{A}$ & $100 \%$ & $100 \%$ & $=91 \%$ & $182 \%$ & $75 \%$ & $=51 \%$ & $31 \%$ & $100^{\circ}$ & $100 \%$ & $100 \%$ & $93 \%$ & $=81 \%$ & $775 \%$ & $=52 \%$ \\
\hline & B & - & - & $5 \%$ & $11 \%$ & $15 \%$ & $29 \%$ & $28 \%$ & - & - & - & $4 \%$ & $10 \%$ & $11 \%$ & $32 \%$ \\
\hline & $\mathrm{C}$ & - & - & $4 \%$ & $6 \%$ & $8 \%$ & $11 \%$ & $26 \%$ & - & - & - & $3 \%$ & $9 \%$ & $10 \%$ & $11 \%$ \\
\hline & D & - & - & - & $1 \%$ & $2 \%$ & $9 \%$ & $15 \%$ & - & - & - & - & - & $4 \%$ & $6 \%$ \\
\hline \multirow{4}{*}{ Surface texture } & $\overline{\bar{A}}$ & $100 \%$ & $100 \%$ & $96 \%$ & $\overline{89 \%}$ & $\overline{881 \%}$ & $=76^{\circ} \%$ & 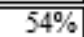 & $=\frac{100^{\circ}}{2}$ & $100 \%$ & $=100 \%$ & $\bar{~} 92 \%$ & $86 \%$ & 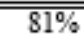 & $\overline{669 \%}$ \\
\hline & B & - & - & $3 \%$ & $5 \%$ & $8 \%$ & $9 \%$ & $21 \%$ & - & - & - & $5 \%$ & $9 \%$ & $11 \%$ & $14 \%$ \\
\hline & $\mathrm{C}$ & - & - & $1 \%$ & $3 \%$ & $6 \%$ & $8 \%$ & $14 \%$ & - & - & - & $3 \%$ & $5 \%$ & $6 \%$ & $11 \%$ \\
\hline & D & - & - & - & $3 \%$ & $5 \%$ & $7 \%$ & $11 \%$ & - & - & - & - & - & $2 \%$ & $6 \%$ \\
\hline \multirow{4}{*}{$\begin{array}{l}\text { Marginal } \\
\text { integrity }\end{array}$} & $\overline{\bar{A} \mathrm{~A}}$ & $\overline{1100 \%}$ & $\overline{100 \%}$ & $94 \%$ & $88 \%$ & $81 \%$ & $68 \%$ & $59 \%$ & $100^{\circ}$ & $100 \%$ & $100 \%$ & $\overline{95 \%}$ & $89 \%$ & $81 \%$ & $76 \%$ \\
\hline & B & - & - & $2 \%$ & $4 \%$ & $5 \%$ & $12 \%$ & $15 \%$ & - & - & - & $2 \%$ & $4 \%$ & $7 \%$ & $8 \%$ \\
\hline & $\mathrm{C}$ & - & - & $4 \%$ & $6 \%$ & $11 \%$ & $15 \%$ & $17 \%$ & - & - & - & $3 \%$ & $7 \%$ & $9 \%$ & $11 \%$ \\
\hline & D & - & - & - & $2 \%$ & $3 \%$ & $5 \%$ & $9 \%$ & - & - & - & - & - & $3 \%$ & $5 \%$ \\
\hline \multirow{4}{*}{$\begin{array}{l}\text { Gum problems in } \\
\text { conformity with } \\
\text { Loe \& Silness } \\
\text { gingival index (GI) }\end{array}$} & $0=A$ & $100 \%$ & $100 \%$ & $89 \%$ & $\overline{777 \%}$ & $68 \%$ & $59 \%$ & 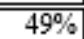 & $100^{\circ}$ & $100 \%$ & $100 \%$ & $87 \%$ & $79 \%$ & $71 \%$ & $61 \%$ \\
\hline & $1=\mathrm{B}$ & - & - & $11 \%$ & $18 \%$ & $21 \%$ & $19 \%$ & $21 \%$ & - & - & - & $7 \%$ & $11 \%$ & $15 \%$ & $21 \%$ \\
\hline & $2=\mathrm{C}$ & - & - & - & $3 \%$ & $7 \%$ & $13 \%$ & $17 \%$ & - & - & - & $6 \%$ & $11 \%$ & $8 \%$ & $11 \%$ \\
\hline & $3=D$ & - & - & - & $2 \%$ & $4 \%$ & $9 \%$ & $13 \%$ & - & - & - & - & - & $6 \%$ & $7 \%$ \\
\hline \multirow[t]{2}{*}{ Cervical caries } & $\mathrm{A}$ & $100 \%$ & $100 \%$ & $\overline{100 \%}$ & $\overline{996 \%}$ & $\overline{994 \%}$ & $92 \%$ & $91 \%$ & $100^{\circ}$ & $100 \%$ & $100 \%$ & $99^{\circ}$ & $\overline{\mid 99 \%}$ & $\overline{997 \%}$ & $\overline{95 \%}$ \\
\hline & $\mathrm{B}$ & - & - & - & $4 \%$ & $6 \%$ & $8 \%$ & $9 \%$ & - & - & - & $1 \%$ & $1 \%$ & $3 \%$ & $5 \%$ \\
\hline \multirow[t]{3}{*}{ Pulp sensitivity } & A & $89 \%$ & (98\% & $97 \%$ & $\overline{96 \%}$ & $\overline{91 \%}$ & 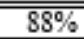 & (86\% & $92 \%$ & $\overline{99 \%}$ & $98 \%$ & $97 \%$ & $94 \%$ & $94 \%$ & $92 \%$ \\
\hline & B & $11 \%$ & $2 \%$ & $3 \%$ & $4 \%$ & $9 \%$ & $11 \%$ & $11 \%$ & $8 \%$ & $1 \%$ & $2 \%$ & $3 \%$ & $6 \%$ & $5 \%$ & $7 \%$ \\
\hline & $\mathrm{C}$ & - & - & - & - & - & $1 \%$ & $3 \%$ & - & - & - & - & - & $1 \%$ & $1 \%$ \\
\hline
\end{tabular}


Criterion 5: Cervical caries: The rate of cervical caries after three years were higher in the abutments covered with FMPRs coated with Superpont C+B polymer (9\%), than those covered by Royaldent resin (5\%).

Criterion 6: Pulp sensitivity: After three years monitoring, we observed a higher number of teeth with painful sensitivity in the vital abutments covered with FMPRs coated with Superpont C+B polymer (9\%) than in those coated by Royaldent resin, caused by the problems of marginal integrity.

In figure 3 are presented aspects of three metalpolymeric prosthetic restorations of two patients, at the third year recall.
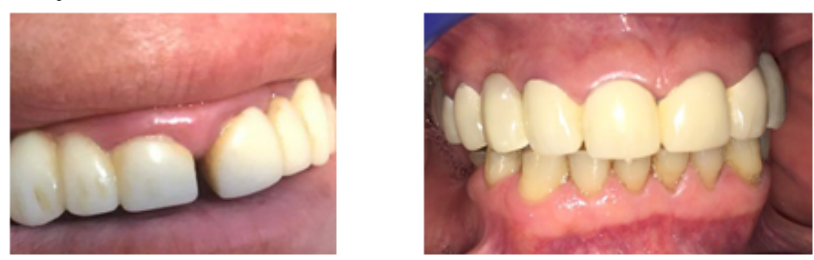

Fig. 4. Metal-polimeric bridges at $3^{\text {rd }}$ year recall: Superpont $C+B$ (left); Royaldent (right)

Different factors such as saliva characteristics, chewing or thermal and chemical dietary changes may be responsible for the biodegradation of acrylic based resins [18]. Polymer degradation does not occur as a result of isolated processes, multiple factors as saliva, chewing, thermal and chemical dietary changes may be responsible for the biodegradation processes [19]. Multiple factors ranging from non retentive tooth preparation, poor casting fit, poor cementing technique, weak cement, to malocclusion, excessive forces of mastication and improper usage of prosthesis, influence the apparition of microleakage $[20,21]$.

Actually, a large variety of possibilities are to opt for a superior prosthetic restoration, in terms of physical properties, aesthetic and biocompatibility. The prosthetic restorations may be perfected, leading to material strength and aesthetics. The materials for prosthetic restorations must have mainly some properties, as strength and durability, respectively aesthetics [4,22]. Good long-term clinical performance of prosthetic restorations is of interest and importance for patients, dentists, because these enhance the general health and satisfaction of patients $[23,24]$. The obtained results in dentistry depend on of what the patient wants. In order to help for a good choice of the patient, the dentist should explain all the advantages and disadvantages of the used materials. Despite competition that exists between ceramic and polymeric prosthetic restorations, the lastones are still among the mostcommon aesthetic restorative materials [25]. For financial considerations, unfortunately still today in our country there are many cases in which these types of prosthetic restorations are used.

One of the most important requirements for an ideal dental material is represented by their biocompatibility [26]. The major significance of biological compatibility of the dental materials used for the achievement of FMPR are in references with their placement in direct contact with the soft and hard dental tissues of oral cavity and with the response of involved tissues to these materials, with positive or negative influences on the final result $[27,28]$.

\section{Conclusions}

The results of the study revealed that both dental resins presented different degree of degradations in time, from the point of view of their physical and their aesthetics appearance, which induced the apparition of discolorations, modifications of surface texture and of marginal integrity, gingival inflammation, cervical caries and pulp sensitivity, butFMPRs coated with Royaldent resin presented better qualities in comparison with FMPRs coated with Superpont C+B.

An adequate oral hygiene and professional care can reduce the problems regarding the modified Ryge criteria used in this study, in both type of FMPRs coated with the two studied resins.

On the basis of the results and despite the limitations of this study, we concluded that both dental polymers presented reasonable clinical performance over an evaluation period of three years, reported at the cost price.

\section{References}

1.BHANDARI S, ARAS M, CHITRE V. The J ournal of the Indian Prosthodontic Society. 2012;12(2):65

2.NUGALA B, KUMAR BS, SAHITYA S, KRISHNA PM,. Journal of Conservative Dentistry/ : JCD. 2012;15(1):12

3.GHIBAN, N., BORTUN, C.M., BORDEASU, I., GHIBAN, B., FAUR, N., CERNESCU, A., HANGANU, S.C, Mat. Plast. 47, no. 2 ,2010, p. 240

4.CRAIG RG, POWERS J M, et al, Dental Materials. 11th ed. St Louis: Mo, Mosby; 2002. pp. 636-689

5.0 BRIEN WJ. Dental Material and their selection. 4th ed. Chicago: Quintessence Publishing Co, Inc.; 2008. p. 75-113

6.*** https://www.britannica.com/science/polymethyl-methacrylate

7.*** www.spofadental.com/.../superpont-cb/productfamily/ SuperpontCB

8.*** http://www.polymerprocessing.com/polymers/PMMA.html

9.*** http://plastics.ulprospector.com/generics/3/c/t/acrylicpropertiesprocessing

10.*** https://www.britannica.com/science/polymethyl-methacrylate 11.ARDELEAN, L., BORTUN, C., PODARIU, A.C., RUSU, L.C., Rev. Mat. Plast., 49, no. 1, 2012, p. 30

12.*** http://www.palatinal.hu/img/hasznalati/javitoanyag.pdf

13.PHILLIPS R, Skinners s Science of Dental Materials, 9 th ed, 1991, Philadelphia, WB Saunders Co, p.193-212

14.ROSU, S., Mat. Plast., 51, no. 1, 2014, p. 110

15. HICKEL R, PESCHKE A, TYAS M, MJÖR I, BAYNE S, PETERS M, HILLER KA, RANDALL R, VANHERLE G, HEINTZE SD. Clin Oral Investig. 2010 Aug;14(4):349

16.*** zep01793.dent.med.uni-muenchen.de/.../FDI Recommendat... 17.HICKEL R, BRÜSHAVER K, ILIE N, Dent Mater. 2013 Jan; 29(1): 2850

18.BETTENCOURT AF, NEVES CB, DE ALMEIDA MS, PINHEIRO LM, OLIVEIRA SA, LOPES LP, CASTRO MF. Dent Mater. 2010 May;26(5):e17180

19.SANTERRE JP, SHAJII L, LEUNG BW. Crit Rev Oral Biol Med 2001;12:136

20.ANUSAVICE KJ, Phillips'science of dental materials. 11th ed. Saunders, Missouri, p. 456-460

21.LINDQUIST TJ, CONNOLLY J, J Prosthet Dent. 2001;85:292

22. MIESZKO W, OPITZV, RICHTER G,BOENING KW, BioMed Research International 2014:15(2), 98

23.CHADWICK B, TREASURE E, DUMMER P, DUNSTAN F, GILMOUR A, JONES R, PHILLIPS C, STEVENS J, REES J, RICHMOND S, Journal of Dentistry, 2001, 29(3) 155

24.MANHART J , CHEN HY, HAMM, \& HICKEL R, Operative , 2004, 29(5) 481

25.POP, DM., NEGRUTIU, M.L., COJ OCARIU, A.C., CRACIUNESCU, E.L., PIRTE, A., SINESCU, C., Rev. Chim. (Bucharest)., 66, no.4,2015, p. 575 26.HANCU, V., COMANEANU, R.M., COMAN, C., FILIPESCU, A.G., GHERGIC, D.L., COTRUT, M.C., Rev. Chim. (Bucharest), 65, no. 6, 2014, p. 706

27.CERNAT, R.I., MOCANU, R.D., POPA ,E., SANDU, I., OLARIU, R.I., ARSENE, C., Rev. Chim. (Bucharest), 61, no. 11, 2010, p. 1130 28.PETRESCU, H.P., BERCEANU VADUVA, M., DINU, G., BRATU, D.C, BERCEANU VADUVA, D., Rev. Mat. Plast., 50, no. 1, 2013, p. 53 